\title{
赤外線熱画像と可視画像によるコンクリート構造物 の劣化診断技術の開発と適用
}

\author{
久保 昌史 ${ }^{* 1} \cdot$ 天野 勲*2 $*$ 中山 聡子*3
}

\begin{abstract}
概 要 現在, 社会基盤施設の点検は, 点検員による近接目視・打音調查に頼っている。しかし, この方法では点検員 および診断技術者の経験や能力の違いにより診断結果にばらつきが生じたり，デー夕整理や図化が煩雑となる等の課題が ある。こうした課題を解決するために, 対象となるコンクリート構造物に対して赤外線熱画像と可視画像を連続的に同時 撮影し, その画像を接合して画像解析することで, 構造物のひび割れや浮き・剥離などの表面劣化を効率的に抽出する非 接触型調査診断システムを開発し，鉄道トンネル，道路トンネル，およびコンクリート壁に適用した。

キーワード：非破壊調查, 赤外線熱画像, パッシブ法, 可視画像, 画像解析
\end{abstract}

\section{1.はじめに}

高度経済成長期に大量に整備された社会基盤施設の老 朽化が進んでおり，建設後 50 年以上経過した道路構造 物の割合は，20 年後には，橋梁 $65 \%$ ，トンネル $45 \%$ に なると予測されている11。

昨今の地球温暖化が原因と考えられる自然災害の激化 や，年々高まる南海トラフ地震や首都直下地震発生の危 険性，少子高齢化や経済低迷による制約された予算環境 等を考えると，こうした社会基盤施設の老朽化対策とし て, 維持管理による構造物の延命化や利用者の安全性を 確保することが今後益々重要になると考えられる。その ためには，構造物の状態を点検や診断によって，今以上 に継続的かつ正確に把握していかなければならない。

現在, コンクリート構造物の点検や診断は, 主に点検 員による目視・打音調査に頼っている。しかし，この方 法では点検員の経験や能力の違いにより結果にばらつき が生じる，構造物の大きさによっては大掛かりな足場が 必要となり効率が低下する, デー夕整理や図化作業が煩 雑になるといった課題がある。

こうした課題を解決するために，対象構造物を画像撮 影し, その画像から変状の抽出および図化を行い記録し てデータを蓄積することが重要である。

現在, 主にトンネルや橋梁等を対象とした画像診断シ ステムが実用化されている2)。これらは可視画像方式に より CCD カメラやビデオカメラ, ラインセンサーカメ ラを用いて対象面を連続的に撮影, 画像化し変状展開図 を作成するもの，レーザー方式により対象面にレーザー を照射し反射光をセンサーで認識し画像化することでひ

*1くぼ・まさふみ / 清水建設(株) 主査

*2 あまの・いさお/株保全工学研究所 代表取締役 (正会員)

*3 なかやま・さとこ/(侏保全工学研究所 係長
び割れを抽出するもの，赤外線方式により対象面を強制 加熱しその温度差を赤外線サーモグラフィ（以下，「赤 外線カメラ」）で撮影することにより表面の浮き・剥離 を抽出するもの等で，一般的には車載型で道路や軌道を 走行しながら撮影するため装置が大掛かりとなる3)。

また，ひび割れを抽出する可視画像方式やレーザー方 式では，表面的な差異がない浮きを抽出することは困難 であるため，赤外線方式等の異なる手法が必要となる。

こうした状況の中, 筆者らは移動可能な撮影架台に搭 載した赤外線カメラとデジタルカメラによりパッシブ方 式による赤外線熱画像と可視画像を同じ画角で連続的に 同時撮影し，これらの画像を効率的に重ね合わせて画像 解析することにより, 構造物のひび割れや浮き・剥離等 の変状を抽出する画像診断システムを開発し4), 現在ま でに鉄道トンネルや道路トンネルをはじめ 10 件程度適 用している。

本稿では，開発した技術の概要および適用事例につい て報告する。

\section{2. 技術の概要}

\section{1 特 徵}

本技術は, 従来の点検員による目視・打音調査の代替 となる非接触型画像診断システムで，コンクリート構造 物の赤外線熱画像と可視画像を連続的に撮影し, これら の画像を解析することで変状を抽出する。

写真-1 に撮影状況を，写真-2 に撮影機材を示す。ま た，図-1に画像解析の流れを示す。

本技術の特徴を以下に示す。

(1)人力により機材の搬入・搬出および運搬ができ，短 時間で装置の組立てが可能でコンパクトな撮影装置 を用いているため, 現地での作業が省力化できる。

(2)赤外線カメラによる熱画像とデジタルカメラによる 


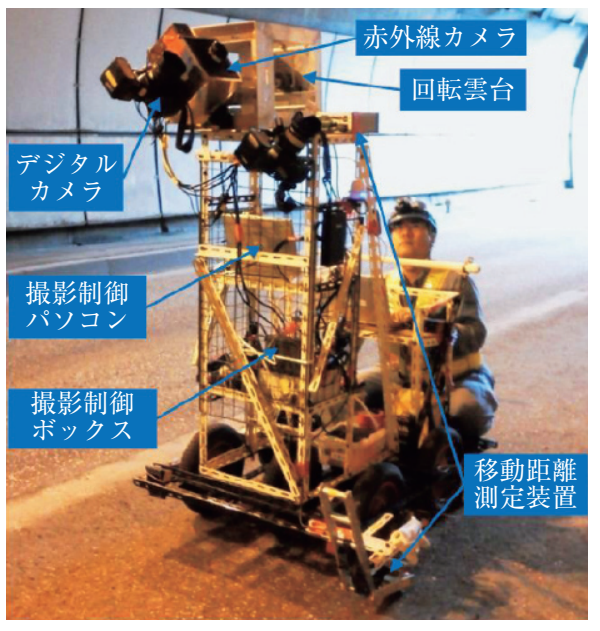

写真-1 撮影 状 況

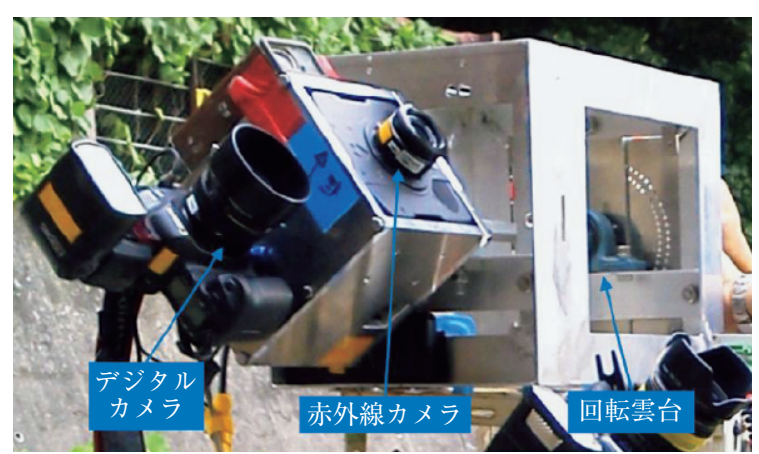

写真-2 撮影機材

可視画像を同じ画角で連続撮影し，幾何補正（画像 補正，縮尺補正）および画像接合を行い，コンクリー トの表層部に生じているひび割れや浮き・剥離など の変状を効率的に抽出し図化できる。

(3)非接触のため足場が不要であり，現地作業時間が短

く構造物の供用に影響が少ない。

\section{2 測 定 原 理}

変状の抽出にあたっては, 赤外線パッシブ法と可視画 像法の原理を用いる。

赤外線パッシブ法とは，測定対象物の表面温度を強制

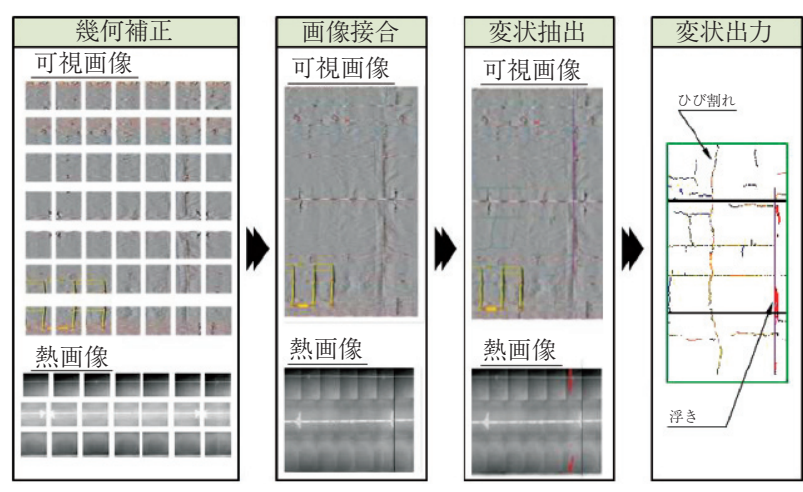

図-1＼cjkstart画像解析の流れ

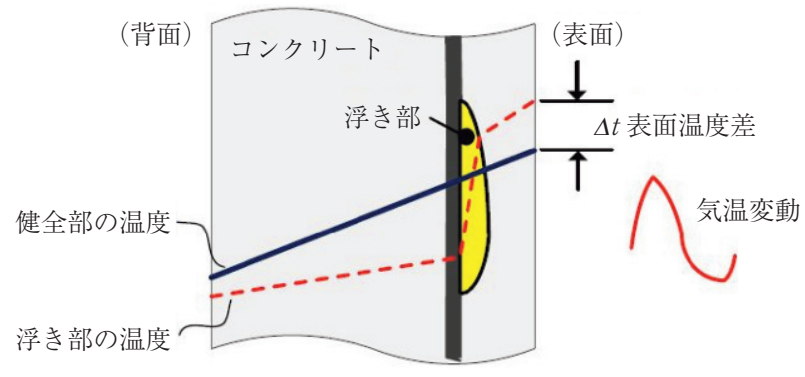

図-2＼cjkstart浮き・剥離の測定原理

的な加熱や泠却をすることなく自然状態で測定し，熱画 像として表示することで, その温度差と, 温度差の生じ ている範囲から，浮き・剥離，表層部の内部空洞および 漏水などを検出する手法である ${ }^{5)}$ 。熱画像では, 浮き. 剥離がある場合は，図-2に示すように，その背面に空 気層が介在するため, 健全部に比べて温まりやすく冷め やすい特徵を有しており，表面の温度差として表示され る。漏水は, 流出している水の温度として表示される。

一方, 可視画像法とは, デジタルカメラで撮影した可 視画像から，ひび割れ，豆板，鉄筋露出およびエフロ レッセンス等の変状を抽出する手法である。これらの変 状のうち，ひび割れについては，コンクリート表面の濃 淡特性から，デジタル画像処理を行うことで，ひび割れ 幅と長さをコンピューター上で抽出する。

Development and Application of Concrete Inspection and Diagnostic Analysis System with Infrared and Visible Images

By M. Kubo, I. Amano and S. Nakayama

Concrete Journal, Vol.52, No. 8, pp.644 651, Aug. 2014

Synopsis The inspection of social infrastructure facilities currently relies on close visual inspection and tapping inspection by inspectors. However, these methods present a number of issues, including the fact that they produce discrepant diagnostic outcomes owing to differences in the experience and ability of inspectors and diagnostic engineers, and require complex data organization and plotting processes. To overcome such challenges, a non-contact inspection and diagnosis system was developed that allows the efficient identification of cracks and surface degradation such as lifting and peeling of structures through continuous and simultaneous acquisition of infrared images and visible images of the target concrete structure and image analysis of the combined images. Further, this system was applied to railway tunnels, road tunnels, and concrete walls.

Keywords : nondestructive inspection, infrared image, passive method, visible image, image analysis 


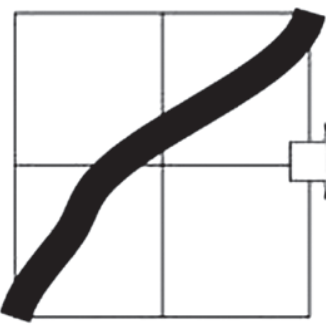

アナログのイメージ

図-3 デジタル画像処理のひび割れのイメージ

表-1 赤外線カメラ

\begin{tabular}{c|c}
\hline \multicolumn{2}{c}{ 寸法・性能 } \\
\hline 温度分解能 & $0.02^{\circ} \mathrm{C}$ 以下 $@ 30^{\circ} \mathrm{C}$ \\
\hline 検出 波長 & $3 \sim 5 \mu \mathrm{m}$ \\
\hline 検出素子 & $\mathrm{InSb}$ \\
\hline 素 子 数 & $640 \times 512$ \\
\hline
\end{tabular}

表-2 可視カメラ

\begin{tabular}{c|c}
\hline \multicolumn{2}{c}{ 寸法・性能 } \\
\hline 有効画素数 & 21 メガピクセル $(5616 \times 3744)$ \\
\hline 撮 像 素子 & $36 \times 24 \mathrm{~mm}$ フルサイズ CMOS \\
\hline
\end{tabular}

一般にひび割れ部は外光反射がなく黒色を呈するた め, 可視画像では, 図-3に示すように灰色のコンクリー 卜面にひび割れが黒色の線上に映った画像となる。この 画像の色調の変化により，ひび割れ幅の抽出を行う。さ らに，抽出したひび割れの連続性を認識することで，ひ び割れの長さも抽出することができる。

ひび割れ以外の変状は, 可視画像からその範囲を測定 する。ただし，これらのうち，剥離や漏水については赤 外線熱画像でも検出される場合があるため, 双方の画像 から人が判定する。

\section{3 診断の流れ}

\section{(1) 現地撮影}

現地撮影は, 移動式架台に搭載した赤外線カメラとデ ジタルカメラにより行う。本システムに用いる機器の仕 様を表-1，表-2に示す。

移動式架台には，移動距離を測定するための距離計, 撮影の制御や記録を行うための撮影制御ボックスおよび パソコン等を搭載する (写真 -1$)$ 。これらの装備は，分 割して人力で運搬・組立ができる。

撮影対象となる構造物に対して, 赤外線カメラとデジ タルカメラの撮影範囲を同じ画角になるように調整し静 止画像を撮影する。撮影後, 撮影対象面と一定の距離を 保ったまま次の撮影範囲まで移動し，同様の方向・画角 で撮影する。その際，隣り合う画像同士を接合して連続 した画像を作れるように，双方の撮影範囲の端部を $20 \%$ 以上ラップさせる。これらの作業を繰返し，連続撮影す ることにより対象範囲の画像を取得する。

本技術においては現在，使用する画像は静止画像を用

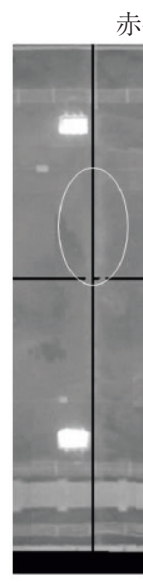

画像
赤外線熱画像

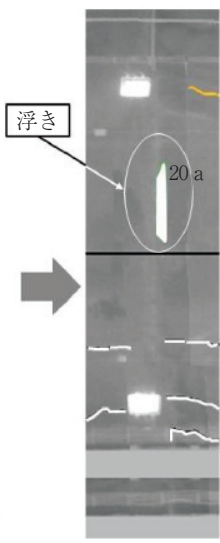

抽出

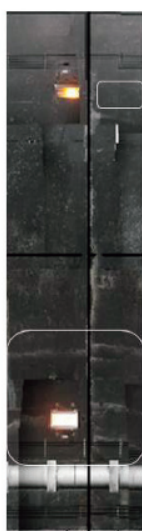

画像
可視画像

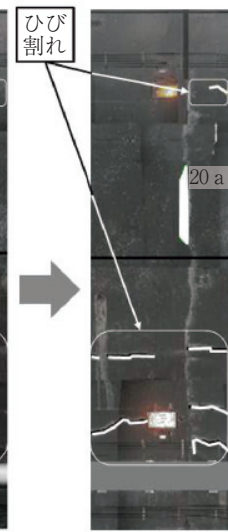

抽出
写真-3 画像解析による変状抽出の例

いている。これは初期の開発段階において実施した実験 により，移動速度がひび割れの精度に及ぼす影響が大き いことが明らかになったためである。

\section{（2）画像解析}

現地で撮影した赤外線熱画像と可視画像を接合し，画 像解析を行って変状を抽出する。画像解析による変状抽 出の例を写真-3に示す。

まず，撮影した赤外線熱画像と可視画像のひずみを除 去し，それぞれの画像の縮尺をそろえ，重ね合わせを行 う。その後，対象物に正対した形の平面図展開図となる ようにそれぞれの画像の幾何補正（あおり補正やたる補 正等）を行い，撮影画像の接合を行う。

画像接合の際に，現地での撮影距離や画角および方向 等の条件が異なるとそれぞれの画像に対して異なった幾 何補正が必要となり非効率となるが，本システムの撮影 手法では，これらの条件が同一となっているため，最初 の赤外線画像と可視画像の補正を行えば，それ以降は同 様の処理を行えばよい。また，視覚的に特徵の多い可視 画像を接合すれば，特徵点の少ない赤外線熱画像も同時 に接合されることとなる。

本システムでは, 複数の画像を効率的に接合すること が可能であり，その後，変状の抽出結果のばらつきを抑 えるために画像の濃淡補正を行い，画像解析ソフトを使 用して，浮き・剥離およびひび割れを抽出する。

赤外線熱画像からは，対象範囲内で，周囲の平均的な 温度から，まとまりをもってある温度差を超える部分を 浮き・剥離として抽出する。通常, 周囲の大気温度が対 象面より高温の場合，対象面への吸熱作用が生じ，背面 に空隙のある浮き・剥離部は，より速く熱せられるため 温度上昇が速くなり健全部より高温となる。一方，周囲 の大気温度が対象面より低温となる場合は，逆により速 く放熱するため，浮き・剥離部は低温となる。

可視画像からは，ひび割れは外光反射がなく黒色の線 状に映った画像になることを利用して画像処理により， ひび割れ長さと幅を抽出する。なお，その他の変状（漏 


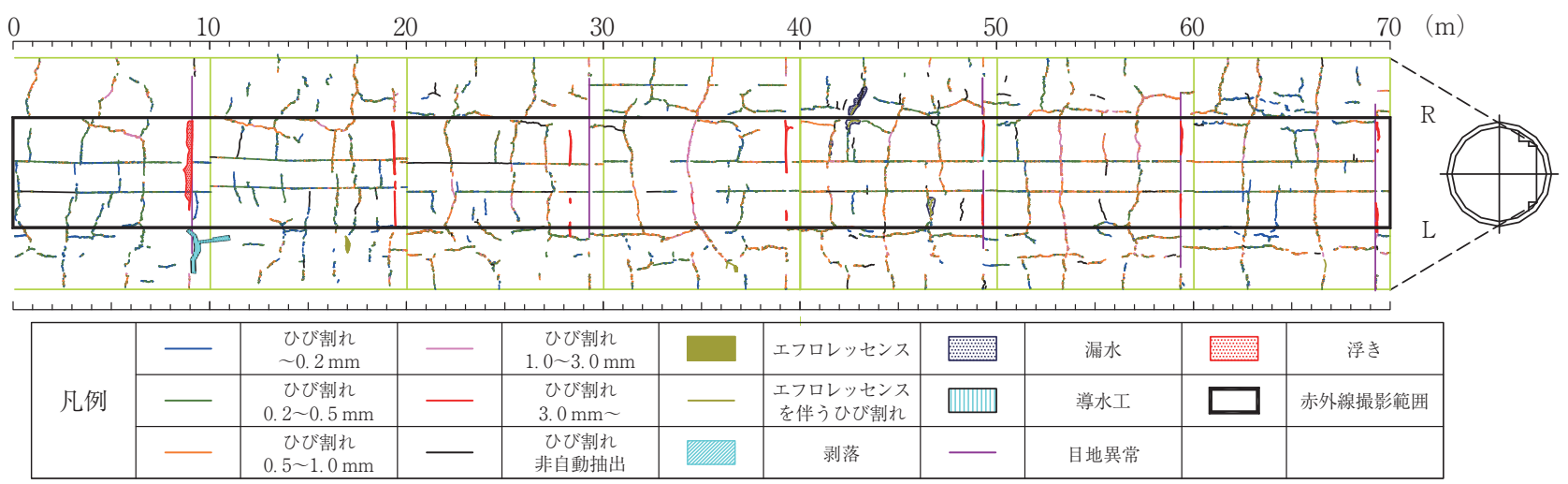

図-4＼cjkstart変状展開図

水, 豆板, 鉄筋露出, エフロレッセンス等）については, 前述したとおり，撮影した画像から人が判定する。

\section{3. 適用事例}

\section{1 鉄道トンネル}

シールド工法で施工された鉄道トンネルの二次覆工コン クリート（内径 $\phi 4800 \mathrm{~mm}$ ）を対象として調査を行った。

この調査は，トンネル直上での鋼管杭打込みおよび地 盤改良工事による近接施工の影響の有無を確認したもの で，工事の進渉に合わせて，平成 22 年 7 月から平成 24 年 6 月にかけて合計 6 回実施した。調査区間は工事の影 響があると考えられる $70 \mathrm{~m}$ とした。現地作業は，最終 電車出発後から始発電車到着 1 時間前までの約 3.5 時間 で，機材搬入，組立，搬出を含めたすべての撮影を完了 することができた。図-4に 1 回目の変状展開図を示す。 撮影は，内径 $\phi 4800 \mathrm{~mm}$ の覆工コンクリートのうち, コンクリートの剥落により鉄道運行に支障が生じる恐れ がある上面約 $90^{\circ}$ の範囲については赤外線熱画像と，可 視画像を，その他の範囲は可視画像のみを撮影した。 表-3に調查実施時期と工事状況を示す。

トンネル内の温度変化を測定した結果，1日の温度差 は $4.8^{\circ} \mathrm{C}$ と小さかった。また, 浮き部と健全部との温度

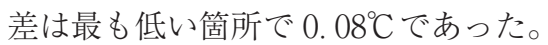

このことより，温度変化の小さいトンネル内において も本システムが適用可能であることが実証された。

表-4にひび割れ，浮き集計結果を，図-5に調査延長 $10 \mathrm{~m}$ ごとのひび割れ長さおよびひび割れ幅の変化を示 す。ここで，東日本大震災は 3 回目の調査後に発生して いる。

1 ～回目の期間は，ひび割れ幅および長さに若干の 増減がみられるが坑内温度がほぼ等しいことから誤差の 範囲と考えられる。

$2 \sim 3$ 回目の期間は，ひび割れ幅が大きくなっている。 コンクリートは温度により伸縮しその線膨張係数は 10 $\times 10^{-6} /{ }^{\circ} \mathrm{C}$ 程度である。3 回目測定時の坑内温度は前回と 比較して $6{ }^{\circ} \mathrm{C}$ 低下している。覆工コンクリートは 1 スパ ン $10 \mathrm{~m}$ で, 線路直角方向には平均 1 スパンに 4 本程度

\section{表-3＼cjkstart調査実施時期と工事状況}

\begin{tabular}{|c|c|c|c|}
\hline & 調査実施日 & 坑内温度 & 工事進渉 \\
\hline 1 回目 & H 22. 7.13 & $28^{\circ} \mathrm{C}$ & 着手前 \\
\hline 2 回目 & Н 22. 10. 15 & $28^{\circ} \mathrm{C}$ & \multirow{2}{*}{ 鋼管杭打込み } \\
\hline 3 回目 & Н 23.3 .3 & $22^{\circ} \mathrm{C}$ & \\
\hline 4 回目 & H 23. 6.3 & $25^{\circ} \mathrm{C}$ & \multirow{2}{*}{$\begin{array}{c}\text { 地盤改良 } \\
\text { (高圧噴射工法) }\end{array}$} \\
\hline 5 回目 & Н 23. 8.5 & $29^{\circ} \mathrm{C}$ & \\
\hline 6 回目 & Н 24. 6.7 & $25^{\circ} \mathrm{C}$ & 施工完了 \\
\hline
\end{tabular}

表-4 ひび割れ，浮き集計結果

\begin{tabular}{|c|c|c|}
\hline ひび割れ & 延長 (m) & 浮 き \\
\hline 幅 $0.2 \mathrm{~mm}$ 未満 & 86. 39 & \multirow{8}{*}{ 総面積 $\left(\mathrm{m}^{2}\right)$} \\
\hline 幅 $0.2 \mathrm{~mm}$ 以上 $0.5 \mathrm{~mm}$ 未満 & 227.08 & \\
\hline 幅 $0.5 \mathrm{~mm}$ 以上 $1.0 \mathrm{~mm}$ 未満 & 181.99 & \\
\hline 幅 $1.0 \mathrm{~mm}$ 以上 $3.0 \mathrm{~mm}$ 未満 & 43. 30 & \\
\hline 幅 $3.0 \mathrm{~mm}$ 以上 & 4. 80 & \\
\hline 非自動抽出* & 32.66 & \\
\hline エフロレッセンスを伴う & 3. 45 & \\
\hline 合計 & 579.68 & \\
\hline
\end{tabular}

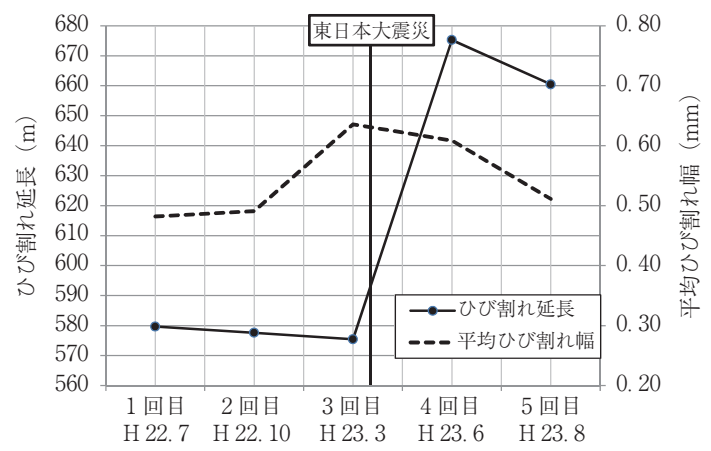

図-5ひび割れ長さおよびひび割れ幅の変化

のひび割れが発生していることから平均ひび割れ間隔は $2.0 \mathrm{~m}$ となる。コンクリートの収縮はスパン内で均等に 生じると仮定するとひび割れ間隔 $2.0 \mathrm{~m}$ では約 $0.12 \mathrm{~mm}$ 収縮することとなる。これは計測值の約 $0.15 \mathrm{~mm}$ にも 近い值であることから，ひび割れ幅の増加は温度低下に 
よりコンクリートが収縮したことが原因と考えられる。

$3 \sim 4$ 回目の期間は，ひび割れ長さが大幅に増加して いる。ひび割れ幅は，坑内温度が $3{ }^{\circ} \mathrm{C}$ 上昇していること から，計算上コンクリートの膨張により約 $0.06 \mathrm{~mm}$ 小 さくなるはずであるが, 計測值は約 $0.03 \mathrm{~mm}$ で計算上 の值ほど小さくなっていない。温度変化が原因であれ ば，ひび割れ長さが短くなり，幅も小さくなるがこの期 間では，そういった傾向はみられなかった。

$4 \sim 5$ 回目の期間は，全体的にひび割れ長さが短くな りかつひび割れ幅も小さくなっている。坑内温度が $4{ }^{\circ} \mathrm{C}$ 上昇していたため, 温度変化の影響が原因として考えら れる。3〜 5 回目の期間は同一工事（地盤改良）が行われ たにもかかわらず，3〜4 回目は温度変化で説明できない ようなひび割れ長さの増加が生じ， 4〜5回目では温度変 化によるひび割れの減少が生じている。図-6に4 回目の ひび割れ変状図の抜粋を示す。東日本大震災の前後でひ び割れ長さが増加し，新規に発生したひび割れはトンネ ル軸直角方向および $90^{\circ} ， 270^{\circ}$ 上のトンネル方向であった。 これらの結果から，3〜4回目に新規に発生したひび割れ は東日本大震災による不等沈下や水平力の影響であり, その他の長さや幅の増減は坑内温度の変化によるもので あると考えられ近接施工による影響は無いと判断した。

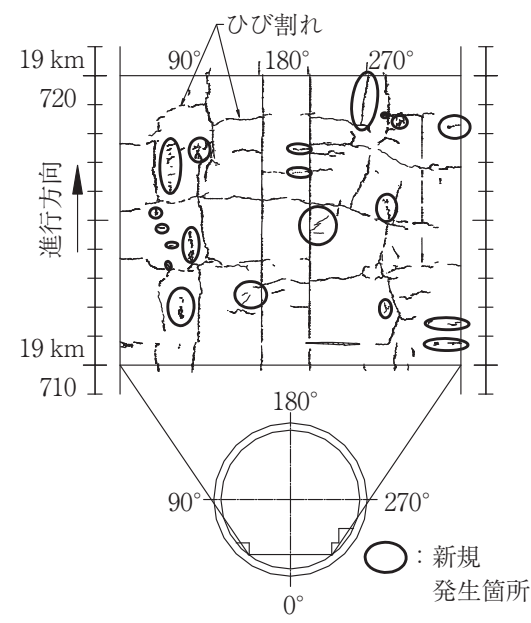

図-6 ひび割れ変状図の抜粋（4 回目）

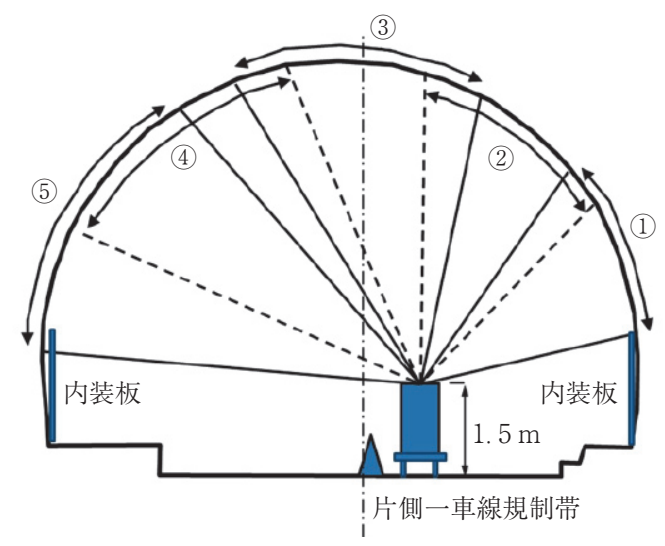

図-7 断面方向の撮影分割範囲

\section{2 道路トンネル}

矢板工法で施工された片側 1 車線の道路トンネルの覆 エコンクリートを対象として調査を実施した。対象のト ンネルは 1979 年に完成し，延長約 515 m（45 スパン), 断面形状は，道路幅員 $7.5 \mathrm{~m}$, 中央高さ $6.8 \mathrm{~m}$, アーチ 半径 $5.1 \mathrm{~m}$ であった。調査延長は，車線規制の関係で計 測が出来なかった範囲を除く約 $450 \mathrm{~m}$ （39 スパン）で, 平成 25 年 10 月 11 日，12 日の 2 日間の昼間に実施した。

撮影は隣接する橋梁補修工事のためトンネル全線に設 置された車線規制内より実施した。

撮影時の天気は両日とも雨時々曇で，当該地区の気温 は，気象庁のデータによれば最高気温 $22.8^{\circ} \mathrm{C}$, 最低気 温 $12.2^{\circ} \mathrm{C}$, 平均気温 $18.6^{\circ} \mathrm{C}$ であった。調查に要した時 間は準備時間や機材の搬入，搬出，組立時間を含めて延 べ約 15 時間，そのうち撮影に要した時間は延べ約 10 時 間であった。

撮影は, 片側 1 車線の規制帯内の道路上から行い,

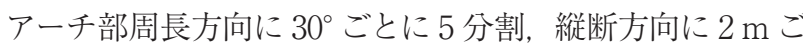
ととして行った。断面方向の撮影分割範囲を図-7に示す。

調査期間中は坑内大気温度と覆工表面温度の変化を把 握するため，両坑口およびトンネル中央付近に温度計を 設置し連続的に計測した。坑内温度計測状況を写真-4 に示す。また, 中央付近のトンネル内の気温と覆工表面 温度の経時変化を図-8に示す。

図-8より，撮影時間帯の温度環境は，1日目は坑内大

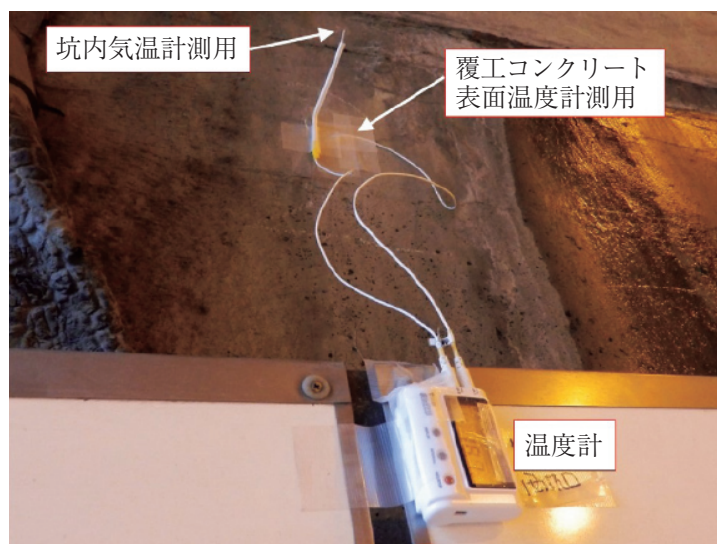

写真-4 坑内温度計測状況

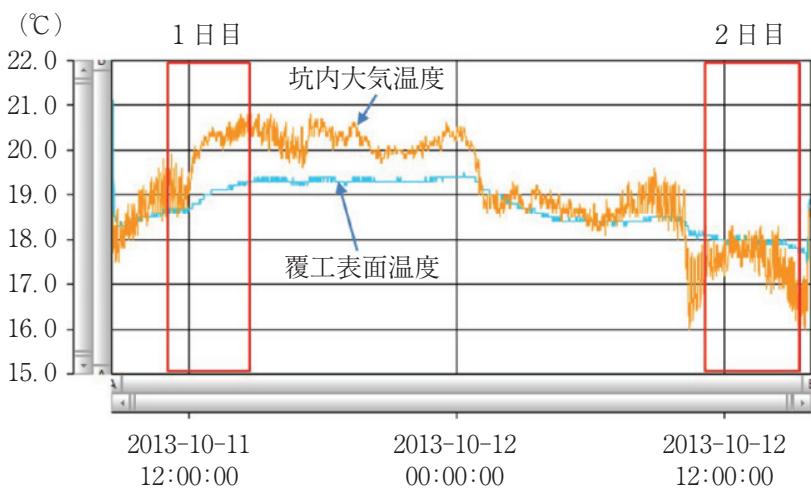

図-8トンネル内の気温と覆工表面の温度変化 


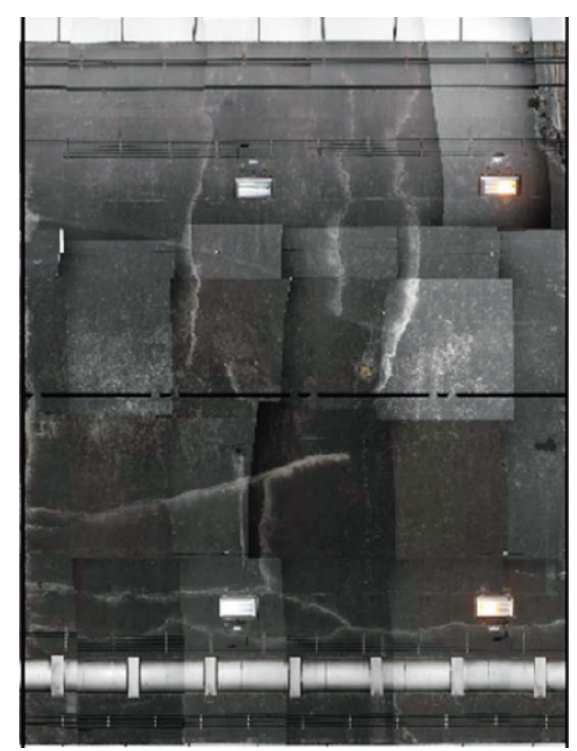

写真-5 可視画像の例

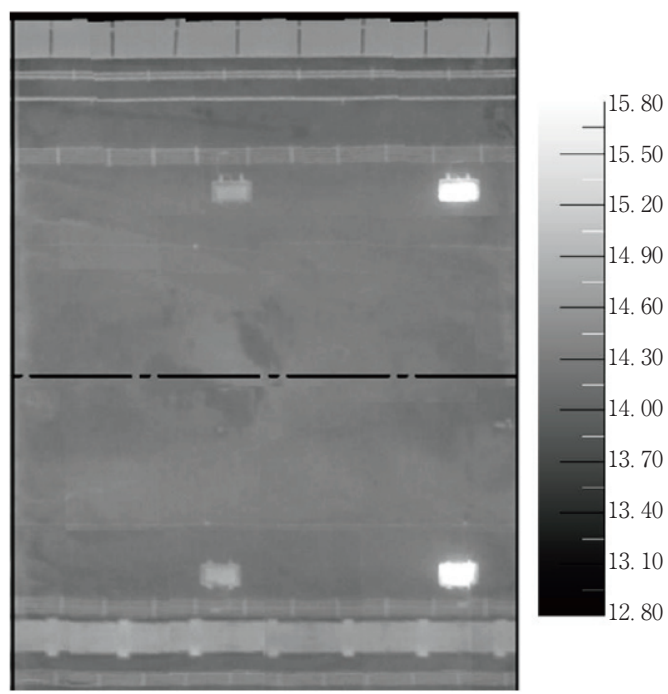

写真-6 熱画像の例

気温度の方が覆工表面温度より $2{ }^{\circ} \mathrm{C}$ 程度高く，浮き・剥 離部は，高温として検出される条件であった。一方， 2 日目は，覆工表面温度と坑内大気温度は時刻により変化 し，撮影区間に応じて浮き・剥離部は高温または低温と して検出される条件であった。

可視画像展開図の例を写真-5に, 熱画像展開図の例 を写真-6に，損傷展開図の例を図-9にそれぞれ示す。

抽出した損傷の数量を調查対象面積（周長×スパン長） で除したひび割れ長さ密度および浮き・剥離面積比率の スパンごとの分布図を図-10，図-11ににそれぞれ示す。

ひび割れ長さ密度は, 16 スパンにおいて $1.07 \mathrm{~m} / \mathrm{m}^{2}$ と最大值を示し，中央部より起点側の方にひび割れは集 中し， 0.05 から $1.07 \mathrm{~m} / \mathrm{m}^{2}$ となっていた。一方，中央 部より終点側では最大で $0.2 \mathrm{~m} / \mathrm{m}^{2}$ と起点側に比べて小 さかった。

また，浮き・剥離の分布は，起点側の 4 から 15 スパ ン間で最大 $20 \mathrm{~cm}^{2} / \mathrm{m}^{2}$ を示したのに対し，27 から 31 ス

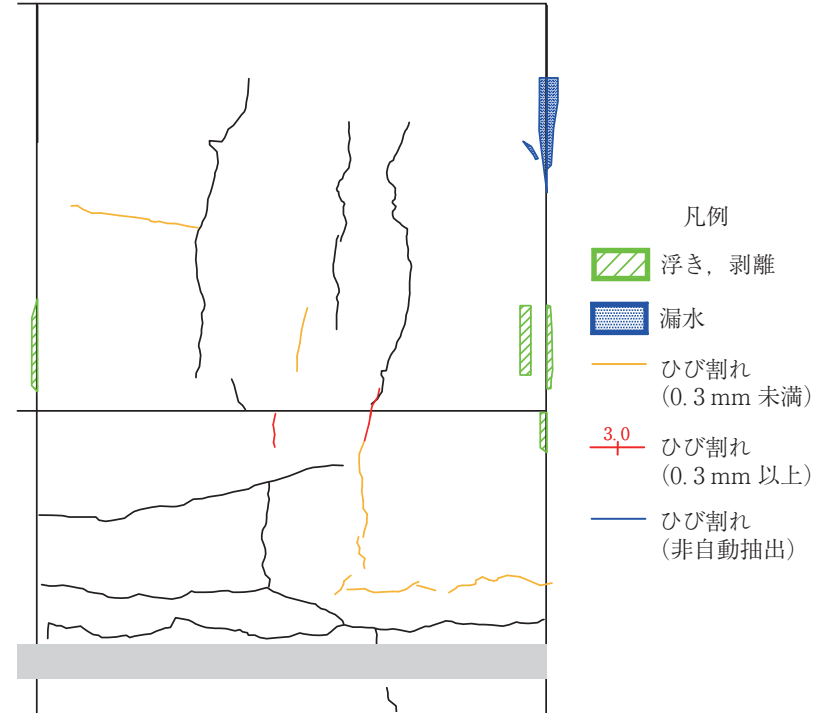

図-9＼cjkstart損傷展開図の例

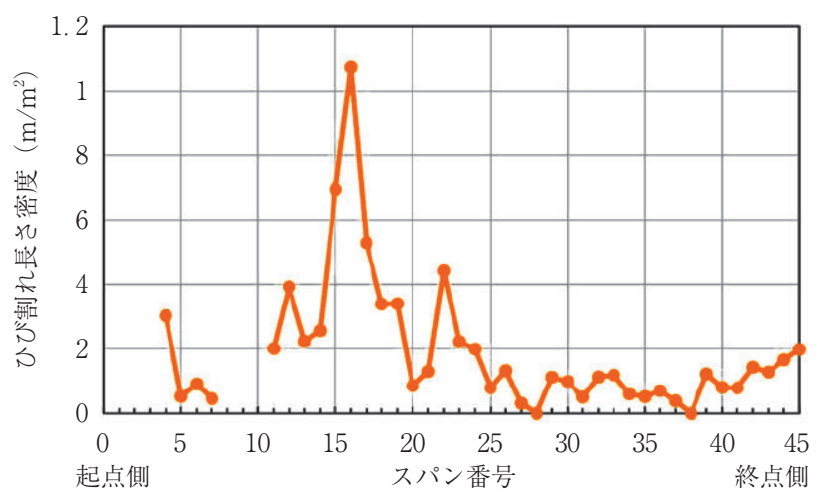

図-10 ひび割れ長さ密度の分布図

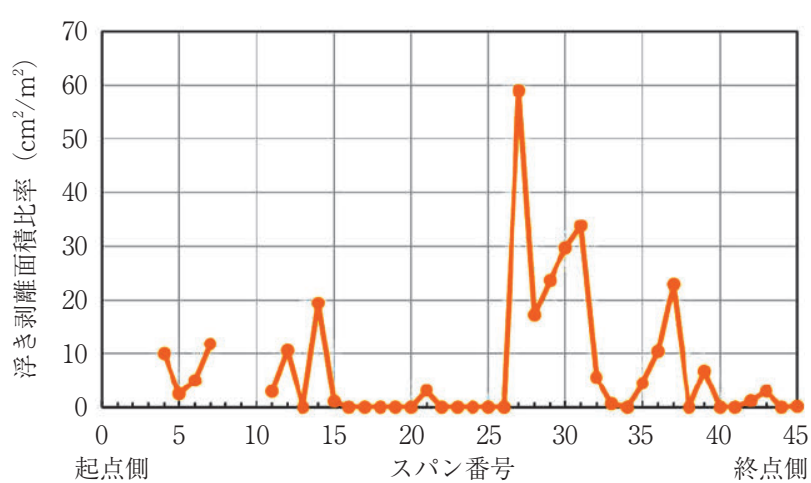

図-11 浮き剥離面積比率の分布図

パン間では 17 から $59 \mathrm{~cm}^{2} / \mathrm{m}^{2}$ と比較的高い值を示した。 また, 37 スパン付近も 10 から $23 \mathrm{~cm}^{2} / \mathrm{m}^{2}$ を示し中央部 より終点側の方に浮きが集中していることがわかった。

ひび割れ長さ密度と浮き剥離面積比率の分布図を図-12 に示す。図-12 より，ひび割れ長さ密度が同程度のスパン であっても，そのスパンの浮き剥離面積比率はばらつい ていて，今回のトンネルに扔いては，ひび割れ長さ密度と 浮き剥離面積比率が相関している傾向はみられなかった。

3.3 コンクリート壁

高さ約 $8 \mathrm{~m}$ のコンクリート壁に対して, 西面 $100 \mathrm{~m}$ と南 


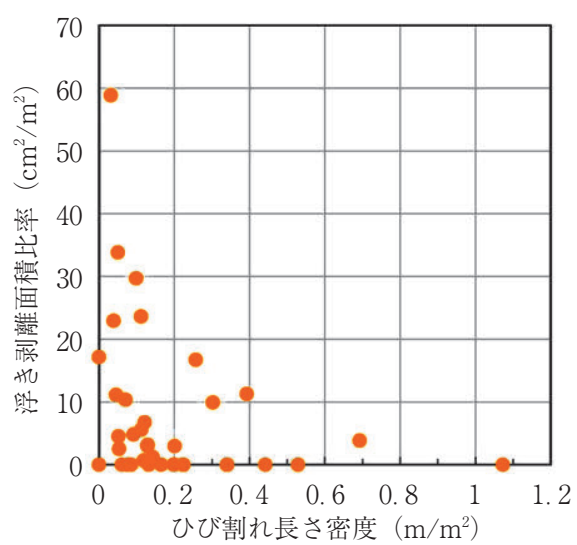

図-12 ひび割れ長さ密度と浮き剥離面積比率の分布図

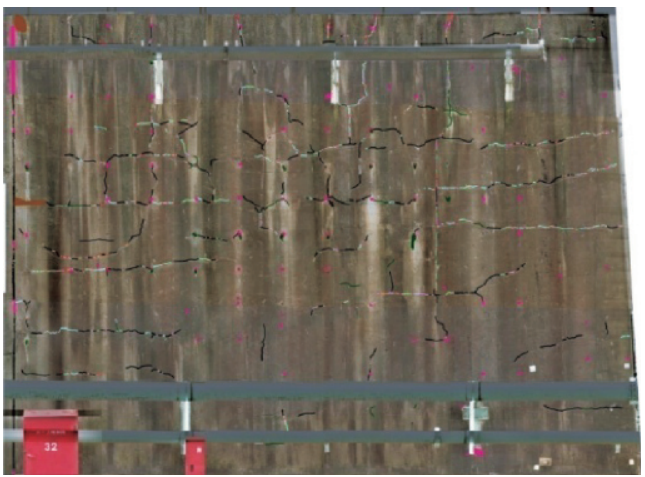

写真-7 可視画像の例

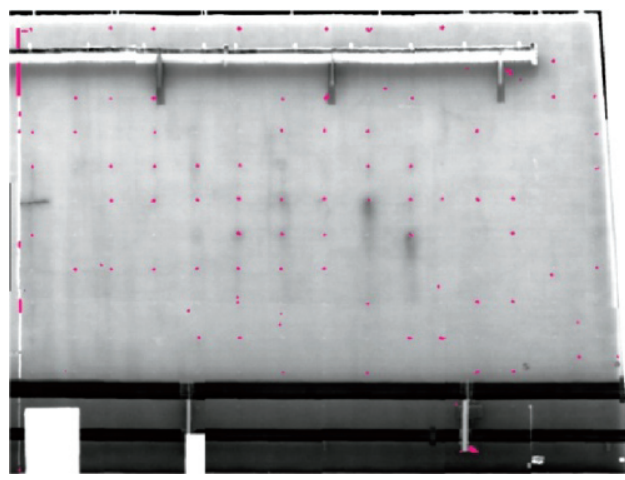

写真-8 赤外線熱画像の例

面 $15 \mathrm{~m}$ ，合計約 $900 \mathrm{~m}^{2}$ を対象として調查を実施した。こ の調査では, 別途，点検員による近接目視および打音調查 も実施したので，本技術との比較検証も合わせて行った。

撮影は，撮影機材を搭載した台車を用いて，長さ方向に $2 \mathrm{~m}$ 間隔で移動しながら行った。高さ方向については, 1 回で撮影できる高さが壁面高さの $1 / 3$ 程度であったため, 上，中，下に3 分割して行った。撮影に要した時間は合計 80 分程度であった。撮影当日の天候は晴時々量, 気温の日 較差は $4.1{ }^{\circ} \mathrm{C} て ゙ ，$ 撮影時間帯のコンクリート表面温度は上 昇傾向にあり $1 \sim 2{ }^{\circ} \mathrm{C} / \mathrm{hr}$ 程度の温度勾配がみられた。

写真-7, 写真-8に可視画像と赤外線熱画像の接合画 像の例を, 図-13に損傷展開図の例をそれぞれ示す。ま た，表-5にひび割れ，浮き集計結果を示す。ひび割れ
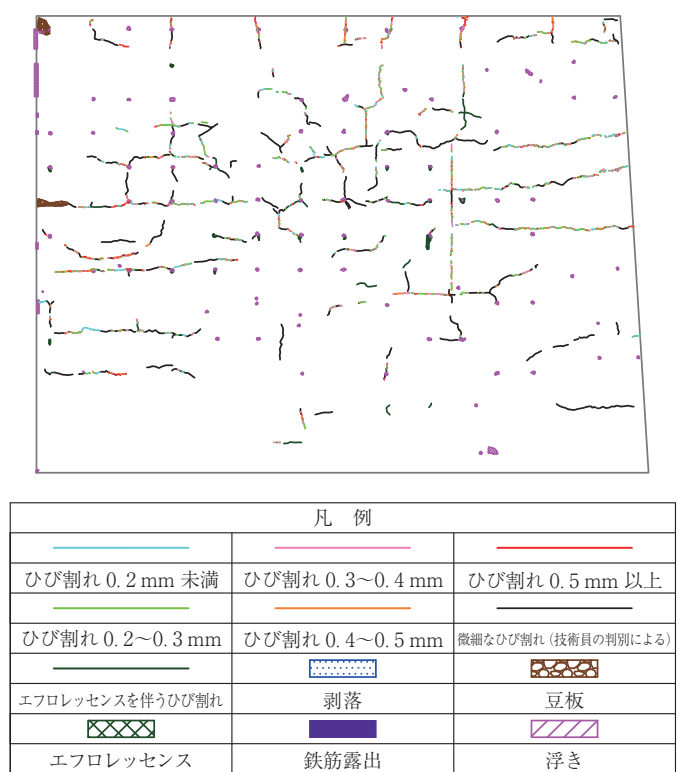

図-13 損傷展開図

表-5 ひび割れ，浮き集計結果

\begin{tabular}{|c|c|c|}
\hline ひび割れ & 延長 (m) & 浮 き \\
\hline 幅 $0.2 \mathrm{~mm}$ 未満 & 6. 17 & \multirow{10}{*}{ 総面積 $\left(\mathrm{m}^{2}\right)$} \\
\hline 幅 $0.2 \mathrm{~mm}$ 以上 $0.3 \mathrm{~mm}$ 未満 & 9.28 & \\
\hline 幅 $0.3 \mathrm{~mm}$ 以上 $0.4 \mathrm{~mm}$ 未满 & 5.79 & \\
\hline 幅 $0.4 \mathrm{~mm}$ 以上 $0.5 \mathrm{~mm}$ 未満 & 3. 01 & \\
\hline 幅 $0.5 \mathrm{~mm}$ 以上 & 2. 78 & \\
\hline 非自動抽出* & 33.57 & \\
\hline 補修されたひび割れ & 4. 42 & \\
\hline ひび割れ長さ合計 & 65.01 & \\
\hline 抽出面積 $\left(\mathrm{m}^{2}\right)$ & 80 & \\
\hline ひび割れ密度 $\left(\mathrm{m} / \mathrm{m}^{2}\right)$ & 0.81 & \\
\hline
\end{tabular}

は水平拉よび鉛直方向ともに微細なものが多く見られ， ひび割れ密度は $0.81 \mathrm{~m} / \mathrm{m}^{2}$ であった。また，浮きは， 大きさ $5 \mathrm{~cm}$ 以上のものが鉄筋露出箇所やその周辺に多 く，それ以下の小さな浮きはセパレー夕頭部の後埋めモ ルタル部に多く見られた。なお，これ以外に，豆板や工 フロレッセンス等も見られた。

本技術を実施した範囲に打ける，点検員による目視・ 打音調查による損傷展開図を図-14 に示す。

目視・打音調查によって確認した，浮き・剥離，鉄筋 露出，豆板およびひび割れ箇所に対して，本技術で確認 した各変状が一致した箇所の割合を表-6に示す。

ここで変状の一致とは，それぞれを比較して，同一と 判断できる変状のこととした。ひび割れの場合について, 変状の一致と判断した例を図-15に示す。

表-6より，セパ跡浮き・剥離箇所を除き変状の抽出 結果はほぼ一致していた。セパ跡の浮き・剥離箇所につ いて変状の一致した割合が低かったのは，セパ跡を埋め た材料はコンクリートと材質が異なることから，その熱 伝導率や比熱等の熱的な性質も異なり，浮きがない場合 でも温度差が計測され，その部分が健全なのか浮きなの 


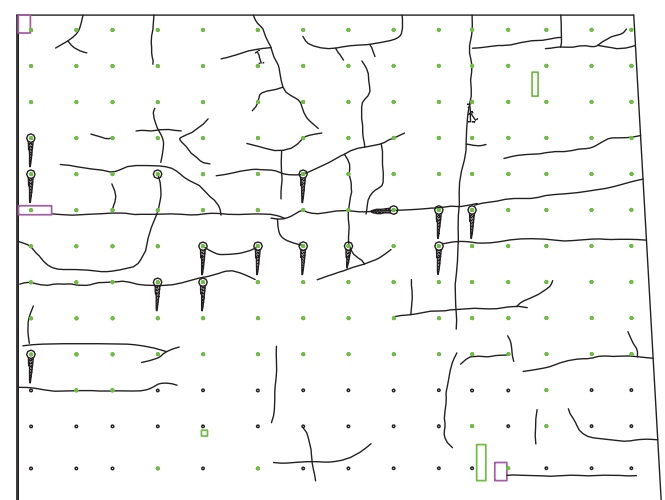

\begin{tabular}{|c|c|c|c|}
\hline 種 類 & 表示凡例 & 種 類 & 表示凡例 \\
\hline 浮き·剥離 & $\infty$ & エフロレッセンス & $=$ \\
\hline 異物 ·鉄筋露出 & 0 & セパ跡·浮き·剥離 & e \\
\hline 豆板 & 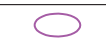 & セパ跡エフロレッセンス & (a) \\
\hline ひび割れ & $\sim<$ & & \\
\hline
\end{tabular}

図-14 目視・打音調査による損傷展開図の例

表-6＼cjkstart変状がー致した箇所の割合

\begin{tabular}{c|c|c|c}
\hline 変 状 & $\begin{array}{c}\text { 目視打音確認 } \\
\text { (箇所) }\end{array}$ & $\begin{array}{c}\text { 本技術で一致 } \\
\text { (箇所) }\end{array}$ & $\begin{array}{c}\text { 割合 } \\
(\%)\end{array}$ \\
\hline ひび割れ & 54 & 49 & 91 \\
\hline 豆板 & 3 & 3 & 100 \\
\hline 浮き・剥離 & 1 & 1 & 100 \\
\hline セパ跡浮き・剥離 & 138 & 76 & 55 \\
\hline
\end{tabular}

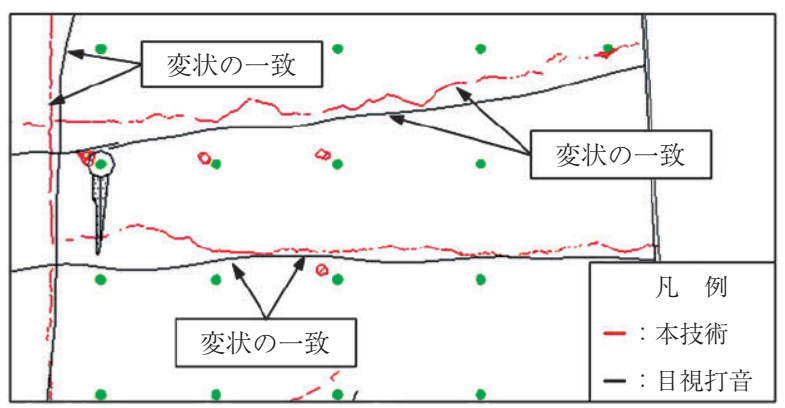

図-15 変状の一致と判断した例（ひび割れの場合）
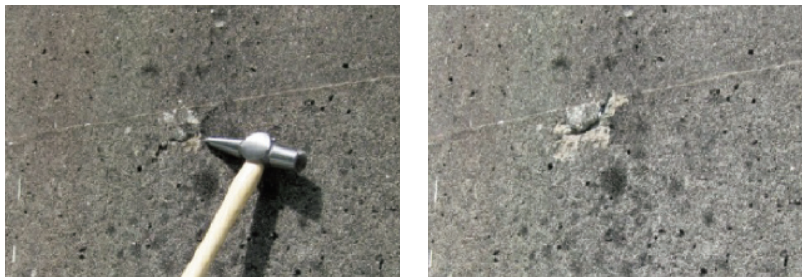

写真-9＼cjkstart本技術で判明した浮き箇所の確認状況

かの判断が難しかったことによると考えられる。

また，浮きに関して打音調査では検出されなかった変 状を本技術で抽出できた箇所（写真-9）もあり，本技術 の精度が高いことが実証できた。

現地調査時間は，本技術では約 1 時間，目視・打音調 查では約 8 時間を要し現地調査に要する時間は $1 / 8$ で あった。調査にかかった費用は, 現地調査費用は少なく なったものの内業にかかる時間を要したためトータルで

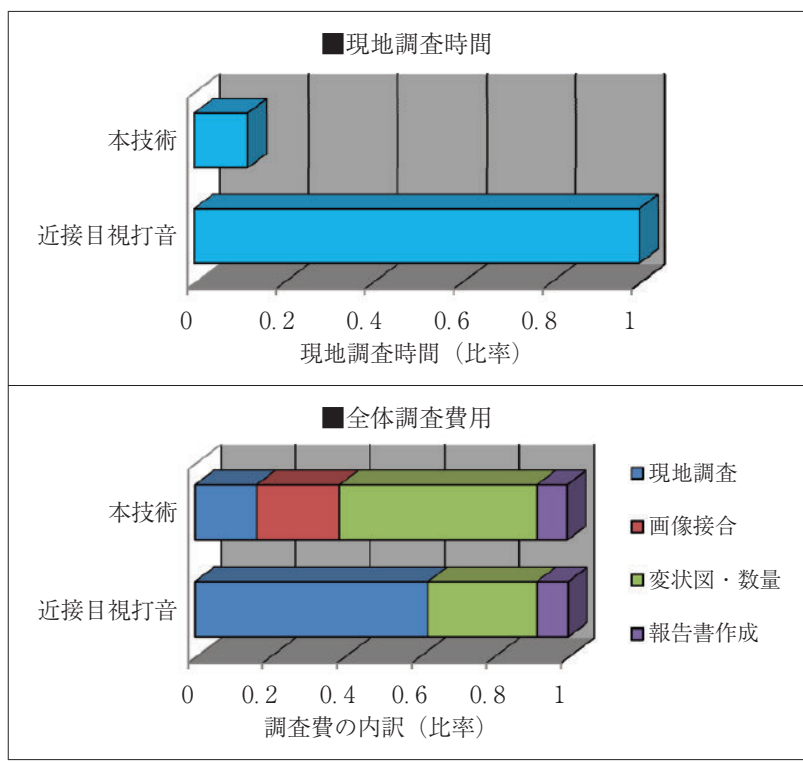

図-16＼cjkstart現地調査時間および全体調査費用の比較結果

は同等であった。図-16に，現地調査時間および全体調 査費用の比較結果を示す。

4.おわりに

本技術は，点検結果を画像化して解析し，データとし て記録に残すため，複数回の点検を実施する場合は，撮 影したすべての範囲において経時的な比較が定量的にで きるため, 変状の進展や変化が把握しやすい。

また，今回紹介した事例以外にも，建築構造物の夕イ ルの浮きやダム堤体のような人が近付きにくい構造物等 にも適用が可能である。

本技術はこのように様々な構造物を対象として調査が できるという利点があるものの，静止画像を用いるため 撮影時は撮影機材を停止させる必要がある。このため, 走行しながら調査を行うことが難しく，道路トンネルの 点検では道路規制が必要となる。

また，赤外線カメラによる浮き・剥離の抽出において は精度が悪くなる場合もある。

今後も継続的に，撮影方法や解析ソフトの改良等によ る走行撮影の可能性についての検討，浮き・剥離の抽出 精度の向上等の課題に取り組んでいきたい。

参 考 文 献

1）国土交通省：社会資本の維持管理・更新に関し当面講ずべき措置, 平成 25 年 3 月 21 日

2）例えば，半田・大西・西山・矢野・西川・下澤：デイジタル画像処 理を利用したひび割れ抽出による道路トンネル健全性評価，第 37 回岩盤力学に関するシンポジウム講演集，pp.13～18, 2008 年 1 月

3）角湯：トンネルにおける維持管理の現状，第 2 回 CAESAR 講演 会, 平成 21 年 8 月 26 日

4） 久保·天野・中山・ファン：赤外線画像と可視画像を併用した画 像診断技術の開発, コンクリート工学年次論文集, Vol.33, No.1, pp.1847 1852, 2011

5）本村・吉田・菅野・藤野：赤外線画像解析法を用いたコンクリー 卜構造物の浮き・剥離の検出, 土木学会第 56 回年次学術講演会 pp.324 325, 平成 13 年 10 月 